\title{
Benign Lacrimal Duct Neoplasm
}

National Cancer Institute

\section{Source}

National Cancer Institute. Benign Lacrimal Duct Neoplasm. NCI Thesaurus. Code C3626.

Abnormal growth of the cells of the lacrimal duct without malignant characteristics. 